Article

\title{
Integration of In Silico, In Vitro and In Situ Tools for the Preformulation and Characterization of a Novel Cardio-Neuroprotective Compound during the Early Stages of Drug Development
}

\author{
Claudia Miranda ${ }^{1}$, Alejandro Ruiz-Picazo ${ }^{2} \mathbb{D}$, Paula Pomares ${ }^{2}$, Isabel Gonzalez-Alvarez ${ }^{2} \mathbb{D}$, Marival Bermejo $^{2} \mathbb{D}$, \\ Marta Gonzalez-Alvarez ${ }^{2, *,+} \mathbb{D}$, Alex Avdeef ${ }^{3}$ and Miguel-Ángel Cabrera-Pérez ${ }^{1, \ddagger \mathbb{D}}$ \\ check for \\ updates \\ 1 Unit of Modeling \& Experimental Biopharmaceutics, Central “Marta Abreu” de Las Villas, \\ Centro de Bioactivos Químicos Universidad, Santa Clara 50100, Cuba; cmiranda@uclv.cu (C.M.); \\ macabrera@uclv.edu.cu (M.-Á.C.-P.) \\ 2 Department Engineering of Pharmacokinetics and Pharmaceutical Technology Area, \\ Miguel Hernandez University, 03550 Alicante, Spain; alejandroruizpicazo@gmail.com (A.R.-P.); \\ paula.pomares@alu.umh.es (P.P.); isabel.gonzalez@goumh.umh.es (I.G.-A.); mbermejo@goumh.umh.es (M.B.) \\ 3 In-ADME Research, 1732 First Avenue \# 102, New York, NY 10128, USA; alex@in-adme.com \\ * Correspondence: marta.gonzalez@umh.es; Tel.: +34-965-919217 \\ + Current address: Edificio Muhammad Al-Shafra, Facultad de Farmacia, UMH, \\ Carretera Alicante Valencia km 87, San Juan de Alicante, 03550 Alicante, Spain. \\ $\ddagger$ Current address: Carretera a Camajuaní, Km 5 1/2, Santa Clara 54830, Cuba.
}

Citation: Miranda, C.; Ruiz-Picazo, A.; Pomares, P.; Gonzalez-Alvarez, I.; Bermejo, M.; Gonzalez-Alvarez, M.; Avdeef, A.; Cabrera-Pérez, M.-Á. Integration of In Silico, In Vitro and In Situ Tools for the Preformulation and Characterization of a Novel Cardio-Neuroprotective Compound during the Early Stages of Drug Development. Pharmaceutics 2022, 14, 182. https://doi.org/10.3390/ pharmaceutics14010182

Academic Editors: Carlo Irace and Jaehwi Lee

Received: 16 November 2021

Accepted: 5 January 2022

Published: 13 January 2022

Publisher's Note: MDPI stays neutral with regard to jurisdictional claims in published maps and institutional affiliations.

Copyright: (C) 2022 by the authors. Licensee MDPI, Basel, Switzerland. This article is an open access article distributed under the terms and conditions of the Creative Commons Attribution (CC BY) license (https:// creativecommons.org/licenses/by/ $4.0 /)$.

\begin{abstract}
The main aim of this work is the biopharmaceutical characterization of a new hybrid benzodiazepine-dihydropyridine derivative, JM-20, derived with potent anti-ischemic and neuroprotective effects. In this study, the $\mathrm{pKa}$ and the $\mathrm{pH}$-solubility profile were experimentally determined. Additionally, effective intestinal permeability was measured using three in vitro epithelial cell lines (MDCK, MDCK-MDR1 and Caco-2) and an in situ closed-loop intestinal perfusion technique. The results indicate that JM-20 is more soluble at acidic $\mathrm{pH}(9.18 \pm 0.16)$; however, the Dose number (Do) was greater than 1 , suggesting that it is a low-solubility compound. The permeability values obtained with in vitro cell lines as well as with the in situ perfusion method show that JM-20 is a highly permeable compound (Caco-2 value $3.8 \times 10^{-5}$ ). The presence of an absorption carrier-mediated transport mechanism was also demonstrated, as well as the efflux effect of P-glycoprotein on the permeability values. Finally, JM-20 was provisionally classified as class 2 according to the biopharmaceutical classification system (BCS) due to its high intestinal permeability and low solubility. The potential good oral absorption of this compound could be limited by its solubility.
\end{abstract}

Keywords: intestinal permeability; Caco-2; solubility-pH; pKa; BCS; JM-20; MDCK

\section{Introduction}

Drug discovery and development processes are extremely costly in both time and money. Today, the number of new synthesized chemical entities with high biological activity but poor physicochemical and biopharmaceutical properties is increasing, limiting new candidates for prescription drugs [1]. The characterization of these properties in the early stages of drug development is very important to avoid potential failures during clinical trials and to stop further development of the drug product.

The Biopharmaceutics Classification System (BCS) [2] is a widely used scientific framework for waiver of in vivo bioequivalence studies, as well as for decision-making in drug discovery and development [3]. This tool classifies drug substances according to solubility/dosage and permeability values as follows: drugs with high solubility/high permeability (Class 1), drugs with low solubility/high permeability (Class 2), drugs with 
high solubility/low permeability (Class 3) and drugs with low solubility/low permeability (Class 4). BCS has proven to be a very important tool for the identification of compounds whose solubility and absorption characteristics may be sensitive to physiological and formulation variables, allowing early optimization in the preformulation stages from the knowledge of the physicochemical properties of the active pharmaceutical ingredient (API) [3]. In this sense, it is evident that new compounds with low permeability and solubility/dissolution will have low and highly variable oral bioavailability, which may limit the chances of developing a clinically useful product.

Classification criteria for solubility and permeability properties according to BCS are not fully harmonized among the major regulatory agencies. For instance, to classify a drug's solubility as high, the World Health Organization (WHO) requires the highest single therapeutic dose to dissolve in $\leq 250 \mathrm{~mL}$ of aqueous medium in the $\mathrm{pH}$ range of 1.2-6.8. The United States Food and Drug Administration (US-FDA) and the European Medicinal Agency (EMA) use for solubility classification the highest dosage strength [4,5]. Regarding drug permeability, there is a consensus on the cut-off value for high permeability (oral absorbed fraction fa higher than $85 \%$ ), as well as on different experimental methods to establish in vivo permeability, such as in vivo or in situ intestinal perfusion studies in animal models and in vitro cells methods (e.g., Caco-2: immortalized cell line of human colorectal adenocarcinoma cells, MDCK: Madin-Darby Canine Kidney Cells). These cell lines are a well-stablished in vitro model for human intestinal permeability, MDCK cells, despite their renal origin, have demonstrated a good correlation with the absorbed human fraction and MDCK-MDR1 and Caco-2 cell lines present the added value of expressing P-glycoprotein [6-9]. In situ permeability studies in rats, either with the single-pass method or closed-loop perfusion method, are also accepted models for permeability classification. All in vitro and in situ models should be internally validated, i.e., demonstrate good correlation of permeability and fa values for a set of model compounds including low, intermediate and high permeability drugs. Validation must be carried out at least once, and the classification test of any new drug is performed by comparison with the permeability of the high permeability model compound, which in general, is metoprolol. Bearing in mind that each permeability model has advantages, disadvantages and a specific domain of application, a combination of these methodologies will provide a better permeability characterization for any new drug candidate [10].

JM-20 (3-ethoxycarbonyl-2-methyl-4-(2-nitrophenyl)-4,11-dihydro-1H-pyrido [2,3-b][1,5] benzodiazepine) is a new hybrid derivate of benzodiazepine-dihydropyridine with high potentiality for neuroprotection in experimental models related to cerebral ischemia. Several in vitro and in vivo models have been performed [11-13] and diverse multitarget mechanisms present in most common neurodegenerative diseases have been demonstrated. Among the most relevant mechanisms are (i) antioxidant and protective activity in brainderived mitochondria [14], (ii) modulation of the glutamatergic system without amnesic or addictive effects [15], and (iii) anti-inflammatory and anti-apoptotic effects [16]. The combination of more than one neuroprotective pharmacophore in the same chemical structure together with the neuroprotective activity demonstrated in vitro and in vivo suggest that JM-20 may be a good candidate in the treatment of Parkinson's and Alzheimer's diseases [17-19]. Although this compound has been widely studied from a pharmacological point of view, its high lipophilicity could limit the distribution properties of the compound in the organism after oral administration, affecting the action on the central nervous system.

Given the limited information on the physicochemical and biopharmaceutical properties of JM-20, it is necessary to classify it into BCS to facilitate future drug development. In the present study, an integration of in silico, in vitro and in situ methodologies was evaluated for the biopharmaceutical characterization of JM-20 according to CS. 


\section{Materials and Methods}

\subsection{In Silico Studies}

Physicochemical and Biopharmaceutical Properties

Properties such as molecular weight (MW), polar surface area (PSA), number of rotatable bonds (RTB), hydrogen bond donors (HBD), hydrogen bond acceptors (HBA), calculated n-octanol/water partition coefficient $(\log \mathrm{P})$ and the dissociation constant $(\mathrm{pKa})$ were predicted for JM-20 using the software MarvinSketch (version 20.3) [20]. Biopharmaceutic properties such as aqueous solubility $(\log S)$, Caco-2 permeability (log Papp) and oral bioavailability $(\mathrm{F})$ were predicted using previous published KNIME workflows [21,22].

\subsection{Experimental Studies}

\subsubsection{Compound, Reagents and Buffer Solutions}

JM-20 was synthesized, purified and characterized as previously reported [23]. It is a reddish, odorless and crystalline powder [23]. This compound was supplied by the Center for Pharmaceutical Research and Development (CIDEM, Havana, Cuba). The rest of the chemicals used during the study were of the highest grade available. All chemicals were purchased from Sigma-Aldrich (Barcelona, Spain).

For the spectroscopic determination of the dissociation constant $(\mathrm{pKa})$, the following buffer solutions were used: (a) $\mathrm{pH}$ 2: $50 \mathrm{~mL}$ of $0.2 \mathrm{M} \mathrm{KCl}, 13 \mathrm{~mL}$ of $0.2 \mathrm{M} \mathrm{HCl}$, and enough distilled water to fill a $200 \mathrm{~mL}$ volumetric flask were added; (b) pH 4-5 range: $2.99 \mathrm{~g}$ of $\mathrm{CH}_{3} \mathrm{COONa} \cdot 3 \mathrm{H}_{2} \mathrm{O}, 14 \mathrm{~mL}$ of $2.0 \mathrm{M} \mathrm{CH}_{3} \mathrm{COOH}$, and enough distilled water to fill $1 \mathrm{~L}$ volumetric flask were added; (c) $\mathrm{pH}$ 6-8 range: $50 \mathrm{~mL}$ of $0.2 \mathrm{M} \mathrm{KH}_{2} \mathrm{PO}_{4}, 22.4 \mathrm{~mL}$ of $0.2 \mathrm{M}$ $\mathrm{NaOH}$, and enough distilled water to fill a $200 \mathrm{~mL}$ volumetric flask were added; (d) $\mathrm{pH}$ 9-10 range: $50 \mathrm{~mL}$ of $0.2 \mathrm{M} \mathrm{H}_{3} \mathrm{BO}_{3}, 32.1 \mathrm{~mL}$ of $0.2 \mathrm{M} \mathrm{NaOH}$, and enough distilled water to fill a $200 \mathrm{~mL}$ volumetric flask were added; and (e) $\mathrm{pH} 11-12$ range: $100 \mathrm{~mL}$ of $0.05 \mathrm{M}$ $\mathrm{Na}_{2} \mathrm{HPO}_{4}, 8.2 \mathrm{~mL}$ of $0.1 \mathrm{M} \mathrm{NaOH}$, and enough distilled water were added to fill a $200 \mathrm{~mL}$ volumetric flask. The JM-20 stock solution was prepared at $500 \mu \mathrm{g} / \mathrm{mL}$ in DMSO $(\leq 2 \% v / v)$ so as not to alter the $\mathrm{pKa}$ value [24].

The $\mathrm{pH}$ measurements were performed using a sensiON ${ }^{\mathrm{TM}}$ (PH31) $\mathrm{pH}$ meter. Standard solutions of JM-20 (10 g/mL were prepared adding $0.2 \mathrm{~mL}$ of the stock solution in $9.8 \mathrm{~mL}$ of each buffer. UV-VIS spectra were recorded on a UV-Vis Spectrophotometer (Thermo Fisher GENESYS ${ }^{\mathrm{TM}}$ 10S, Shanghai, China) between 200 and $400 \mathrm{~nm}$ (2 nm of resolution). All spectrophotometric data were processed in Microsoft Excel (2018).

For the solubility study, six buffer solutions ( $\mathrm{pH} 1.2,3.0,4.0,4.5,6.8$ and 7.4) were prepared following the protocols published in the USP XXXVIII, United States Pharmacopoeia [25], as described above.

\subsubsection{Determination of the Dissociation Constant ( $\mathrm{pKa}$ )}

The experimental $\mathrm{pKa}$ was determined using the spectrophotometric method proposed by Salgado et al. [26]. The absorbance spectra of the JM-20 were acquired at different $\mathrm{pH}$ levels. The wavelengths of maximum absorbance were determined at each $\mathrm{pH}$. Using a plot of observed absorbance versus $\mathrm{pH}$ at these analytical wavelengths (262, 316 and $355 \mathrm{~nm})$, the $\mathrm{pKa}$ values were calculated. To determine these points, the linear equations of the two points closest to the crossing at each curve were solved. The whole procedure was carried out in triplicate and at room temperature $\left(23 \pm 2{ }^{\circ} \mathrm{C}\right)$.

\subsubsection{Thermodynamic Solubility Determination}

Solubility experiments for JM-20 were carried out according to the main regulatory guidelines for biowaivers [27]. The tests were performed at the three recommended $\mathrm{pH}$ values ( $\mathrm{pH} 1.2,4.5$ and 6.8) as well as $\mathrm{pH} 3.5,4.0$ and 7.4 (USP buffer formulations). The shake-flask saturation method proposed by Baka et al. [28] was used in the solubility study and the recommendations of Avdeef et al. were followed to improve the quality of the solubility data [29]. The temperature was regulated at $37{ }^{\circ} \mathrm{C}$. Equilibration times were $6 \mathrm{~h}$ stirring $+18 \mathrm{~h}$ sedimentation. At the end of equilibration, the two phases were 
separated by careful decantation. The samples were analyzed with a Thermo Fisher UV-Vis Spectrophotometer $(\lambda \max =262 \mathrm{~nm})$. A linear range of $2-20 \mu \mathrm{g} / \mathrm{mL}$ was obtained $\left(\mathrm{r}^{2}>0.99\right)$. Once the solubility range was determined, the dose number (Do) was calculated following Equation (1)

$$
\mathrm{Do}=\left(\frac{\mathrm{D}}{\mathrm{Vo}}\right) / \mathrm{Cs}
$$

where $\mathrm{D}$ is the highest strength or highest dose administered (mg) according to FDA or EMA criteria, Vo is the volume of water $(250 \mathrm{~mL})$ and $\mathrm{Cs}$ is the maximum aqueous solubility $(\mathrm{mg} / \mathrm{mL})$. Compounds with Do $\leq 1$ or Do $>1$ are classified as high or low solubility drugs, respectively.

\subsubsection{Refinement of Intrinsic and Salt Solubility}

To develop a solution speciation model, the experimental data of $\log \mathrm{S}-\mathrm{pH}$ were used as input into the computer program $p$ DISOL-X [30]. The computational algorithm considers the contributions of all species present in solution, including all buffer components. The program derives its own implicit solubility equations internally, given any practical number of equilibria and estimated constants. The equilibrium constants are subsequently refined by weighted nonlinear least-squares regression [31]. The method can test for the presence of specific buffer drug species. The program assumes an initial condition of a suspension of the solid drug in a solution, ideally with the suspension saturated over a wide range of $\mathrm{pH}$. The software calculates the species distribution as a consequence of a sequence of additions of standardized strong-acid titrant $\mathrm{HCl}$ to simulate the suspension $\mathrm{pH}$-speciation down to $\mathrm{pH} \sim 0$, the staging point for the subsequent operation. A sequence of perturbations with standardized $\mathrm{NaOH}$ is simulated and the solubility is calculated at each point (in $\mathrm{pH}$ steps of 0.2 ), until $\mathrm{pH} \sim 13$ is reached. The ionic strength is rigorously calculated at each step, and $\mathrm{pKa}$ values (as well as the solubility products and the aggregation and complexation constants) are adjusted accordingly [31]. At the end of the $\mathrm{pH}$-speciation simulation, the calculated $\log \mathrm{S}$ vs. $\mathrm{pH}$ curve is compared to $\log \mathrm{S}$ vs. $\mathrm{pH}$ measured. A $\log$ $S$-weighted nonlinear least squares refinement begins to refine the proposed equilibrium model, using analytical expressions for the differential equations. The process is repeated until the differences between calculated and measured $\log S$ values reach a minimum [31].

\subsection{Permeability Determination}

\subsubsection{Cell Culture and MDCK, MDCK-MDR1 and Caco-2}

MDCK (Madin-Darby Canine Kidney) cells, their transfected clone MDCK-MDR1, and Caco- 2 cells were grown in the modified Dulbecco Eagle medium added with L-glutamine, fetal bovine serum and penicillin-streptomycin. The number of cells seeded in transwells with a surface area of $4.2 \mathrm{~cm}^{2}$ depended on the cell line: 250,000 cells $/ \mathrm{cm}^{2}$ for MDCK and Caco-2 and 150,000 cells $/ \mathrm{cm}^{2}$ for MDCK-MDR1. Experiments were performed between 7 and 9 days for MDCK and MDCK-MDR1 and between 19 and 21 for Caco- 2 cells after seeding. Prior to drug placement, cell monolayer integrity was assessed by measuring transepithelial electrical resistance (TEER). Transport studies were performed on an orbital shaker at $37^{\circ} \mathrm{C}$ and $50 \mathrm{rpm}$. Four samples of $200 \mu \mathrm{L}$ were taken from the receptor side at 0 , 15, 30, 60 and $90 \mathrm{~min}$, and two samples from the donor compartment at the beginning and end of the experiment. A standard experiment was performed with the same buffer for the apical and basolateral compartments in the apical to basolateral (A-B) and basolateral to apical (B-A) directions. The drug concentration was $100 \mu \mathrm{M}$ in all experiments and samples were analyzed immediately by HPLC. The retention time was $2.3 \mathrm{~min}$ at maximum wavelengths $(\lambda \max =260 \mathrm{~nm})$. The conditions used for HPLC analyses were: mobile phase composed of a mixture of $50 \% \mathrm{H}_{2} \mathrm{O}\left(95 \% \mathrm{H}_{2} \mathrm{O}+0.5 \%\right.$ trifluoroacetic $)$ and another $50 \%$ HPLC-grade methanol. The stationary phase composed of a Phenomenex®KJ0-4282 column, with two $2 \mu \mathrm{m}$ filters filled with C-18 microparticles of $40 \mu \mathrm{m}$ size and a Nova Pak C-18 stainless-steel column of $150 \mathrm{~mm}$ length. The method was validated and demonstrated to be adequate regarding linearity $\left(\mathrm{r}^{2}>0.999\right)$, accuracy (relative error $<5 \%$ ), precision or 
repeatability $(\mathrm{SD} \leq 2 \%)$, stability (recovery $=98-102 \%$ ), filter influence (recovery $=98-102 \%$ ) and specificity (interference $<2 \%$ ). The lower limit of quantitation of JM-20 was adequate to interpolate the values obtained in the samples.

The apparent permeability coefficient was calculated according to the following Equation (2):

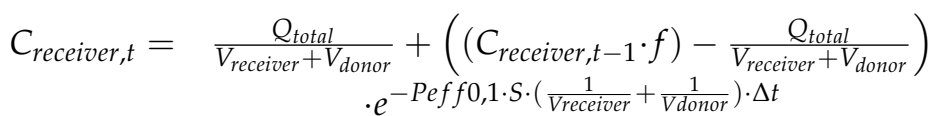

where $C_{\text {receiver, }} t$ is the concentration of the drug in the receiver compartment at the time $t$, $Q_{\text {total }}$ is the total amount of drug in receiver and donor chambers, $V_{\text {receiver }}$ and $V_{\text {donor }}$ are the volumes of receiver and donor chamber, respectively, $C_{\text {receiver, } t-1}$ is the concentration of the drug in receiver compartment at the previous time, $f$ is the replacement dilution factor of the sample, $S$ is the surface area of the monolayer, $\Delta t$ is the time interval and $P_{\text {eff }}$ is the coefficient of permeability, as was described by Mangas-Sanjuan et al. [32] All calculations were developed in Microsoft ${ }^{\circledR}$ Excel (2018).

\subsubsection{In Situ Perfusion Method}

The animal experiments, performed on 250-300 g male Wistar rats, were designed following the guidelines described in EC Directive 86/609, Council of the Europe Convention ETS 123 and Spanish national laws about the use of animals in research, and were approved by the Spanish Committee (Spain, code A1330354541263).

The "closed-loop" in situ perfusion method, based on the Doluisio technique, was performed according to published reports [33]. Briefly, in anesthetized rats in which an abdominal incision was made, the small intestine was located and the bile duct was ligated avoiding enterohepatic circulation of the drug. The procedure for making three loops in the duodenum, jejunum, and ileum was the same as previously described [34]. Intestinal contents were removed by washing with physiological solutions and the peritoneal cavity was covered with cotton wool pads to prevent evaporation of peritoneal fluid and loss of body heat $[35,36]$.

A solution of JM-20 $(100 \mu \mathrm{M})$ was perfused with one syringe, and 5 min later the sample was collected with the other syringe. This procedure was performed alternatively for $30 \mathrm{~min}$ to ensure mixing of the solution in the lumen of small intestine [37,38]. Samples were immediately analyzed for JM-20 at maximum wavelengths $(\lambda \max =262 \mathrm{~nm})$ by HPLC (Alliance-Waters 2695) using a Nova-Pak C18 column $(4 \mu \mathrm{M}, 3.9 \times 150 \mathrm{~mm})$ and UV detector (Waters 2487). The analytical procedure was as follows previously validated [39]. The exact length of the intestine was determined at the end of the study.

The calculation of permeability takes into account that water flux during the experiment can be significant [40], the drug concentration in each sample was modified according to the following Equation (3):

$$
C=C_{e}\left(\frac{V_{T}}{V_{0}}\right)
$$

where $C_{t}$ represents the concentration without water reabsorption at time $\mathrm{t}, C_{e}$ is the experimental concentration value, $V_{0}$ is the initial volume and $V_{t}$ is the final volume. The coefficient of absorption rate $\left(k_{a}\right)$ and the initial concentration of JM-20 available for absorption $\left(C_{0}\right)$ were determined by non-linear regression of the following Equation (4) [41]:

$$
C_{t}=C_{0} \cdot e^{-k_{a} t}
$$

Permeability value was calculated considering the length of the intestinal segment, in other words, the effective intestinal radius $(r)$ considering $10 \mathrm{~mL}$ of perfusion volume by the following ratio (Equation (5)):

$$
\text { Peff }=r \cdot \frac{k_{a p}}{2}
$$




\subsection{Statistical Analysis}

Statistical results are showed as mean \pm standard deviation. Mean values of two groups were analyzed using Student's two tails $t$ tests. A probability level of $p<0.05$ was established as the significance criterion. The software used for the data analysis was SPSS $\mathrm{v}$ 22 (IBM, New York, NY, USA) licensed by the Miguel Hernández University.

\section{Results}

\subsection{In Silico Physicochemical and Biopharmaceutical Properties}

All physicochemical and biopharmaceutical parameters predicted by different computational algorithms are presented in Table 1. As can be appreciated, several physicochemical properties are related to Lipinski rule of five [42] and Veber's rule [43]. Both rules provide information about the potential absorption and oral bioavailability of drugs.

Table 1. Physicochemical and biopharmaceutical predicted properties for JM-20.

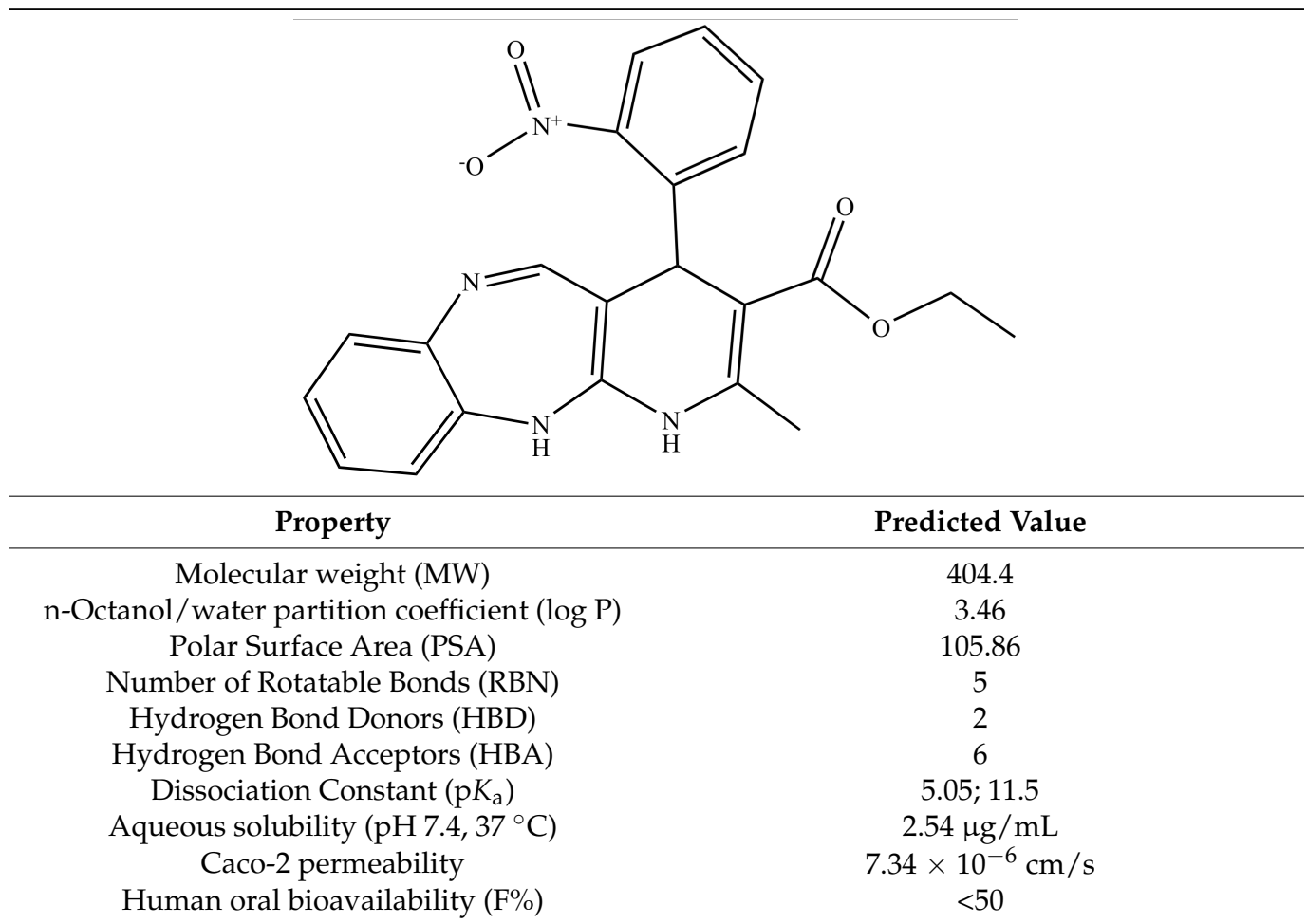

JM-20: Structural formula of (3-ethoxycarbonyl-2-methyl-4-(2-nitrophenyl)-4,11-dihydro- 1H-pyrido[2,3-b][1,5] benzodiazepine).

\subsection{Determination of the Dissociation Constant ( $p K a)$}

Table 1 also represents the predicted $\mathrm{pKa}$ values for the JM-20 ampholyte molecule. Experimental $\mathrm{pKa}$ values obtained for JM-20 with a UV-spectrophotometric method were $\mathrm{pKa} 1=5.48 \pm 0.19$ (base) and $\mathrm{pKa} 2=10.49 \pm 0.17$ (acid) at $23{ }^{\circ} \mathrm{C}$ and ionic strength of approximately $0.1 \mathrm{M}$. Similar results were recently obtained by Martínez et al. with a pKa value of 5.25, using potentiometric titration [44]. The measured $\mathrm{pKa}$ values for JM-20 were comparable to the calculated $\mathrm{pKa}$ values.

\subsection{Solubility Determination}

Figure 1 shows the results of the experimental log S-pH profile for JM-20 (see Table 2) compared to the curve corresponding to the Henderson-Hasselbalch $(\mathrm{HH})$ equation. The results evidence the typical U-shaped curve for ampholyte drugs. The predicted HendersonHasselbalch curve and the log S-pH profile for JM-20 overlap for $\mathrm{pH}>4.5$. Above $\mathrm{pH} 10$, solubility gradually increases. Below $\mathrm{pH} 4.5$, the profile is due to chloride salt formation. 
For $\mathrm{pH}<2$ the line downward, suggesting the potential "common-ion" effect [31]. The intrinsic solubility for JM-20 is $12.0 \mu \mathrm{g} / \mathrm{mL}$.

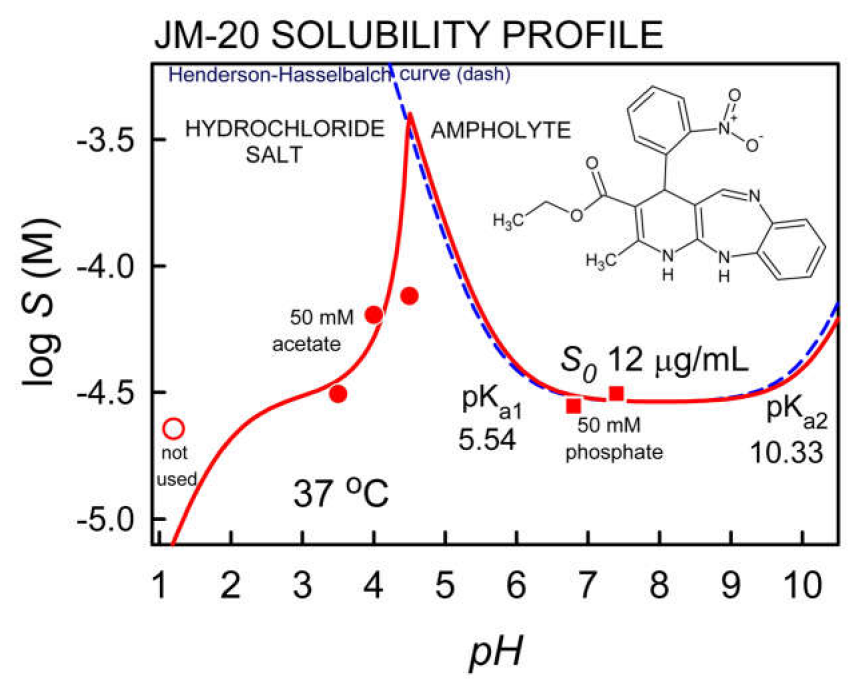

Figure 1. $\mathrm{pH}$-dependent solubility profile of JM-20 (points are solubility values measured by shakeflask method; dashed-line is the theoretical HH curve).

Table 2. Experimental solubility values and number of doses for JM-20.

\begin{tabular}{ccccc}
\hline Buffer Solution & Solubility $^{\mathbf{a}} \pm \mathbf{S D}(\mu \mathrm{g} / \mathrm{mL})$ & Do $^{\mathbf{b}}$ & Solubility $^{\mathbf{c}}(\mu \mathrm{g} / \mathbf{m L})$ & So $^{\mathbf{d}}(\mu \mathrm{g} / \mathbf{m L})$ \\
\hline 1.2 & $9.18 \pm 0.16$ & 61.00 & 3.3 & 12.0 \\
3.5 & $12.72 \pm 0.83$ & 44.03 & 14.3 & \\
4.0 & $25.38 \pm 0.66$ & 22.06 & 18.9 & \\
4.5 & $30.84 \pm 1.29$ & 18.16 & 74.9 & \\
6.8 & $11.30 \pm 0.69$ & 49.56 & 12.5 & \\
7.4 & $12.64 \pm 0.36$ & 44.30 & 11.9 & \\
\hline
\end{tabular}

a The solubility values were determined at $37^{\circ} \mathrm{C},{ }^{b}$ The maximum dose was calculated using the minimum dosed tested on animals $(2 \mathrm{mg} / \mathrm{kg})$ considering $70 \mathrm{~kg}$ as the average weight of a healthy adult. $\mathrm{D}=140 \mathrm{mg}$. ${ }^{\mathrm{c}}$ Solubility calculated by pDISOL-X at $37^{\circ} \mathrm{C}$. ${ }^{\mathrm{d}}$ Intrinsic solubility calculated by pDISOL-X at $37^{\circ} \mathrm{C}$.

The solubility of JM-20 at $\mathrm{pH} 1.2,3.5,4.0,4.5,6.8$ and 7.4 , as well as the dose/solubility ratio for the minimum dose tested in animals $(2 \mathrm{mg} / \mathrm{kg})$ [23], considering $70 \mathrm{~kg}$ as the average weight of a healthy adult, are shown in Table 2 . As can be seen, the highest solubility was observed at $\mathrm{pH} 4.5$, however the dose number $\left(\mathrm{D}_{0}\right)$ is higher than 1 , confirming that JM-20 is a low solubility drug. The $\log$ P value determined in silico was 3.46 (see Table 1), indicating that JM-20 is a lipophilic compound.

Martinez et al. [44] developed a qualitative stability study of JM-20 in aqueous medium at $\mathrm{pH}$ values of $1.2,4.5$ and 6.8 , during $48 \mathrm{~h}$ at $37 \pm 1^{\circ} \mathrm{C}$. At $24 \mathrm{~h}$ some degradation appears at $\mathrm{pH} 4.5$ and 6.8 , but the retention time of JM-20 is the same, and only a decrease in the corresponding areas is observed, so it can be deduced that it has not yet undergone changes in its chemical structure.

According to the product owner (technical report), JM-20 is stable in DMSO and absolute ethanol.

\subsection{Permeability Determination}

\subsubsection{MDCK, MDCK-MDR1 and Caco-2}

In this work, JM-20 permeability was evaluated in three of the most frequent and successful preclinical experimental procedures for predicting intestinal permeability in humans, MDCK, MDCK- MDR1 and epithelial Caco-2 cell cultures. In the case of MDCKMDR1, selection was based on its ability to express P-glycoprotein (Pgp) [9]. The results 
obtained in each in vitro cell model are shown in Table 3. As can be seen, the permeability assay for JM-20 was developed in apical-basolateral and basolateral-apical direction, to evaluate the role of passive, active or facilitating transport and efflux mechanisms.

Table 3. Apparent permeability coefficients (Papp) for JM-20 using MDCK, MDCK-MDR1 and Caco-2 cell lines $\left(37^{\circ} \mathrm{C}\right.$, stirring at $\left.50 \mathrm{rpm}\right)$.

\begin{tabular}{ccc}
\hline Cell Line & $\mathbf{P}_{\text {app }}(\mathbf{A}-\mathbf{B})\left(\times \mathbf{1 0}^{-\mathbf{5}} \mathbf{c m} / \mathbf{s}\right)$ & $\mathbf{P}_{\mathbf{a p p}}(\mathbf{B}-\mathbf{A})\left(\times \mathbf{1 0}^{-\mathbf{5}} \mathbf{~} \mathbf{m} / \mathbf{s}\right)$ \\
\hline MDCK-MDR1 & $2.17 \pm 0.22$ & $0.96 \pm 0.05$ \\
MDCK & $2.46 \pm 0.11$ & $0.28 \pm 0.71$ \\
Caco-2 & $3.83 \pm 0.18$ & $0.85 \pm 0.24$ \\
\hline
\end{tabular}

Figure 2 shows a clear comparison of the permeability values obtained for JM-20 in each cell line with those obtained for metoprolol under the same experimental conditions.

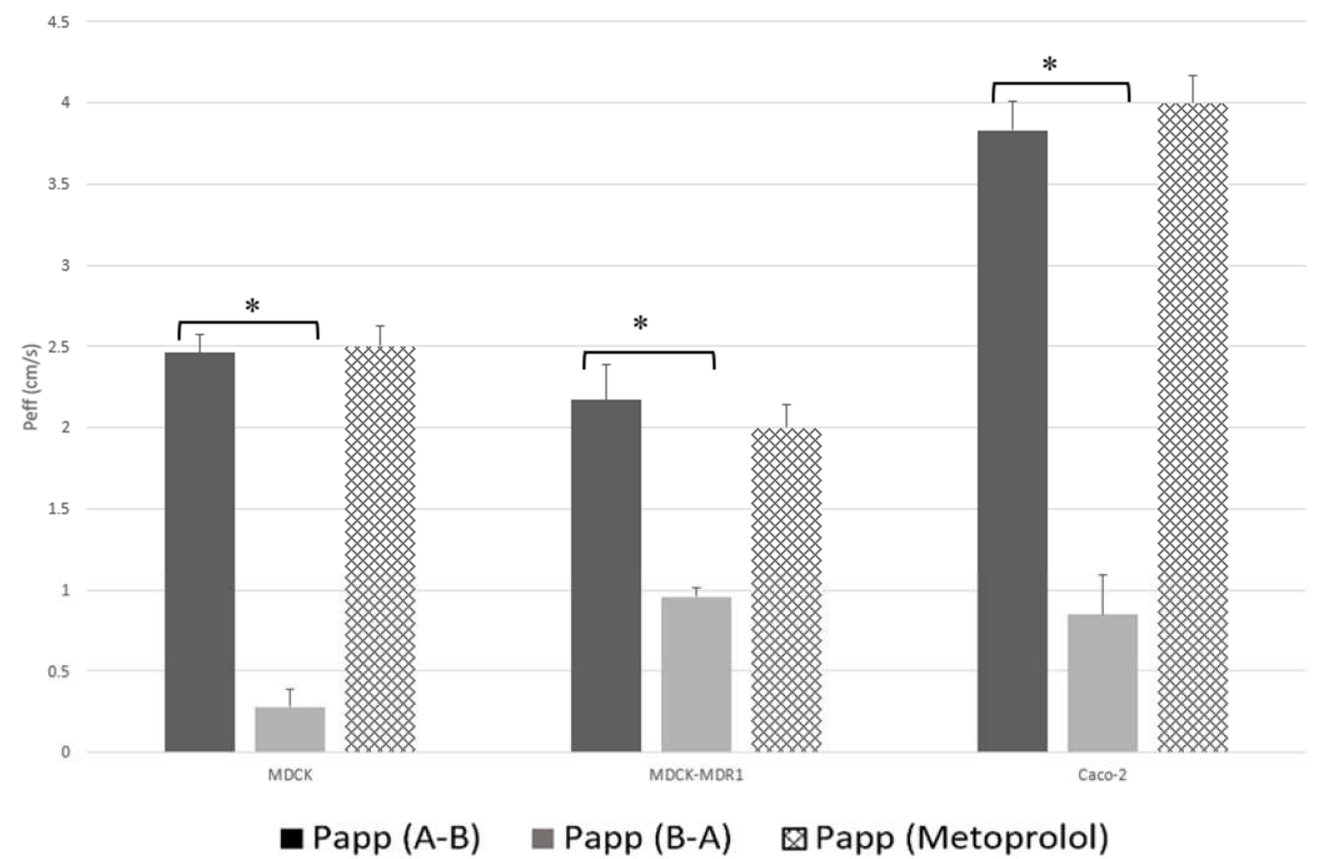

Figure 2. Comparison of apparent permeability values (Papp $\times 10^{-5} \mathrm{~cm} / \mathrm{s}$ ) measured for JM-20 using MDCK, MDCK-MDR1 and Caco-2 cell lines. Results were compared with permeability value of metoprolol. * Significant differences at $p<0.05$.

\subsubsection{In Situ Perfusion Method}

Effective intestinal permeability $\left(P_{e f f}\right)$ data for JM-20, using the Doluisio perfusion model, were evaluated in three segments of the small intestine and the results are presented in Table 4. The effective permeability of JM-20 had the following rank order of duodenum $>$ jejunum $\approx$ ileum. The mean permeability coefficient of this compound was comparable to the reported value of metoprolol used as a high permeability reference compound (see Table 4). This comparison was used to classify this compound according to the BCS.

Table 4. Effective permeability coefficients $\left(P_{\text {eff }}\right)$ and absorption rate coefficient values for JM-20 using in situ rat intestinal perfusion model.

\begin{tabular}{cccc}
\hline Compound & \multicolumn{3}{c}{$\boldsymbol{P}_{\text {eff }} \pm \mathbf{S D}\left(\times \mathbf{1 0}^{-\mathbf{5}} \mathbf{~} \mathbf{m} / \mathbf{s}\right)$} \\
\hline Duodenum & Jejunum & Ileum \\
\hline JM-20 & $9.20 \pm 0.89$ & $6.63 \pm 1.30$ & $6.82 \pm 1.44$ \\
Metoprolol & - & 6.23 & 9.5 \\
\hline
\end{tabular}

Results are shown as mean \pm SD $(n=4)$; Permeability values for metoprolol in the same conditions. 


\subsection{Biopharmaceutical Classification of JM-20}

Different provisional biopharmaceutical classification systems have been described in the literature [45-49]. They mainly use alternative methodologies to predict intestinal permeability. Following the proposal of Kasim et al., JM-20 is a BCS Class 2, based on the aqueous solubility value at room temperature and in silico partition coefficients ( $\log \mathrm{P}$ and $\mathrm{C} \log \mathrm{P})$ [45]. JM-20 is also classified as BCS class 2 compound by the method proposed by Pham-The et al. where a provisional biopharmaceutical classification was developed based on solubility data (dose number, Do) and predicted or measured permeability in Caco-2 cells [48]. At the same time, permeability values of JM-20 obtained with in vitro cell lines and in situ perfusion in rat were considered for the biopharmaceutical classification of this compound. All details of the provisional biopharmaceutics classification are shown in Table 5.

Table 5. A provisional BCS classification for JM-20, based on different in situ, in vitro and in silico permeability models.

\begin{tabular}{ccccccccc}
\hline Compound & $\mathbf{D}_{0}{ }^{a}$ & BCS $_{\log \mathbf{P}}{ }^{\mathbf{}}[45]$ & BCS $_{\text {ClogP }}{ }^{\mathbf{c}}[45]$ & BCS $_{\text {MDCK }}$ & BCS $_{\text {Caco-2 }}$ & BCS $_{\text {QSPeR }}[48]$ & BCS $_{\text {rat }}$ & BCS $_{\text {Global }}$ \\
\hline JM-20 & 61 & 2 & 2 & 2 & 2 & 2 & 2 & 2 \\
\hline
\end{tabular}

a The dose number was calculated with the lowest aqueous solubility; ${ }^{\mathrm{b}}$ The $\log \mathrm{P}$ calculated was 3.46 that was greater than $\log \mathrm{P}$ of Metoprolol (1.72); ${ }^{\mathrm{c}}$ The $\mathrm{C} \log \mathrm{P}$ calculated was 3.11 that was greater than $\mathrm{C} \log \mathrm{P}$ of Metoprolol (1.35).

The clinical repercussion is the human fraction absorbed calculated with Permeability values through Caco-2 monolayers and rat intestine. Results of predictions are summarized in Figure 3.

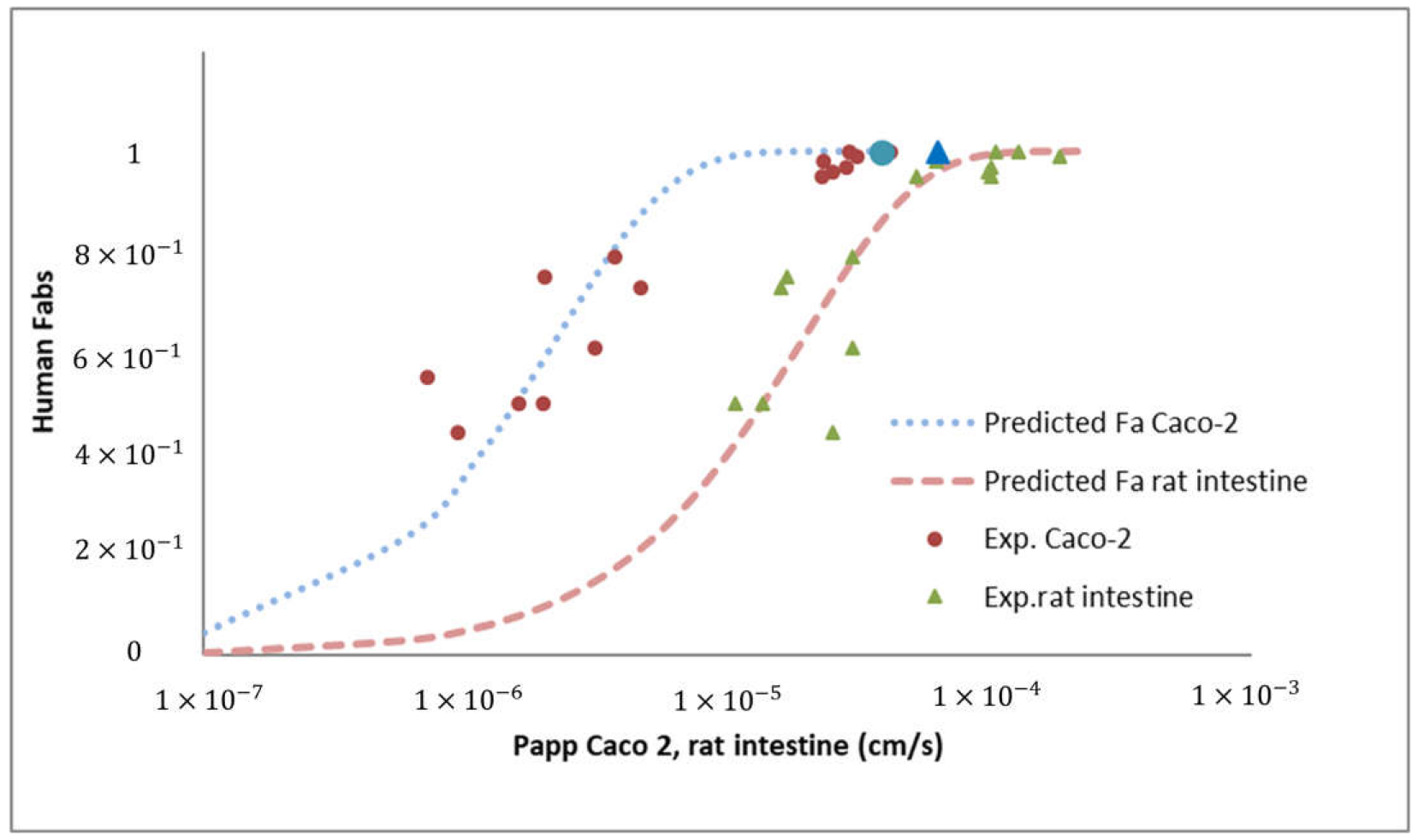

Figure 3. Human fraction absorbed vs. Permeability values in Caco-2 monolayers (apical to basal) or rat intestine. Blue circle and triangle correspond to JM-20 Caco-2 and rat intestine permeability values. Dotted lines correspond to our validated correlation between both techniques and human fraction absorbed [50]. 


\section{Discussion}

The in silico prediction and experimental assessment of the physicochemical properties of active compounds during the early stages of drug and formulation development is quite relevant for estimating the biopharmaceutics class and in vivo behavior of oral drugs.

As can be appreciated in Table 1, the space of predicted physicochemical properties evidenced that JM-20 fulfilled Lipinski's rule of five (MW $<500, \log \mathrm{P}<5, \mathrm{HBD}<5$ and $\mathrm{HBA}<10$ ), and the Veber's rule (PSA < $140 \mathrm{~A}$ and $\mathrm{RBN}<10$ ), suggesting the good absorption potential of this molecule [42], and a probable good oral bioavailability [43]. The predicted values for $\mathrm{pKa}$ (see Table 1) are typical for ampholytes, a kind of molecule with probable poor oral absorption [51]. Nevertheless, the predicted biopharmaceutical properties should be analyzed in details. The predicted aqueous solubility value $(2.54 \mu \mathrm{g} / \mathrm{mL})$ classified JM-20 as a practically insoluble compound, according to USP solubility classification criteria [25]. Meanwhile, the predicted Caco-2 permeability value $\left(7.34 \times 10^{-6} \mathrm{~cm} / \mathrm{s}\right)$, classified JM-20 as a poorly [52,53] or moderately permeable compound [54]. According to these results, JM-20 can be classified as a compound belonging to class II/IV of the BCS, suggesting the evaluation of the influence of absorptive and/or efflux transporters on the absorption process. On the other hand, the low solubility will limit the concentration of JM-20 coming into enterocytes, affecting the fraction of orally absorbed compound. In this sense, the low value of human oral bioavailability $(\mathrm{F}<50)$ predicted for JM-20 [22], is in relation to the predicted solubility and permeability values.

The experimental $\mathrm{pKa}$ values of JM-20 agree with in silico predictions (see Table 1). The $\mathrm{pKa} 1$ value of 5.48 is attributable to protonation of the nitrogen in position 4 of the benzodiazepine ring while the $\mathrm{pKa} 2$ value of 10.49 is attributable to deprotonation of the sp3-carbon of the dihydropyridine ring.

As indicated in Figure 1, the solubility data below pH 4.5 is consistent with the formation of a hydrochloride salt. However, it was not possible to fit the solubility value at $\mathrm{pH} 1.2$ with this salt form. For $\mathrm{pH}>5$ the precipitate is the uncharged ampholyte. Since the $\mathrm{pKa}$ values were determined at $23{ }^{\circ} \mathrm{C}$ and the solubility measurements were performed at $37^{\circ} \mathrm{C}$, the measured $\mathrm{pKa}$ values were transformed to match the temperature of the saturated solutions (i.e., at $37^{\circ} \mathrm{C}$, the $\mathrm{pKa}$ values were estimated to be 5.54 and 10.33 [55].

Considering the lowest dose administered in experimental animal studies $(2 \mathrm{mg} / \mathrm{kg})$, as well as the normal weight of a healthy adult $(70 \mathrm{~kg})$, the final dose used for the calculation of the D/S ratio was $140 \mathrm{mg}$. The calculated Do for JM-20 at different $\mathrm{pH}$ values was greater than 1 , which classifies this compound as a poorly soluble drug.

This result is consistent with statistics indicating that 60 to $70 \%$ of new compounds under development in the pharmaceutical industry have limited aqueous solubility, and in certain drug categories this percentage can be as high as 90\% [56]. Similarly, lowsoluble compounds account for $40 \%$ of the top 200 oral drugs marketed in the U.S., and the water-insoluble or low-soluble categories of the U.S. Pharmacopeia account for more than one-third of all drugs [57]. Consequently, the classification obtained for this new drug-candidate is in line with the current situation on the pipeline in pharmaceutical companies. The absorption of the oral fraction was predicted based on previous data form our laboratory and the conclusion was that a good correlation was obtained between the two. Miyake et al. obtained the correlation between using chamber data and human data [58,59].

For this type of compounds, different formulation strategies should be developed to improve the poor drug solubility, dissolution rate and oral bioavailability [60-62].

In this work, the experimental permeability of JM-20 was determined in three in vitro models such as MDCK, MDCK-MDR1 and Caco-2 cell lines and using the in situ "closeloop" perfusion method in rats.

According to the results obtained in all cell lines (See Table 3), JM-20 can be considered a carried mediated absorption compound. In MDCK cells, a higher permeability is obtained for the A-B direction compared to the B-A direction, which means that the passage of the drug across the membrane is favored by an active or transporter-facilitated mechanism. 
Therefore, in MDCK cells, JM-20 crosses the membrane by passive diffusion and also involves a transporter that aids the passage of the drug from the gut into the blood.

In MDCK-MDR1 cells permeability in the A-B direction is higher than permeability in the $\mathrm{B}-\mathrm{A}$ direction as in the other cell type (significant differences $p<0.05$ ). If the drug only passed by passive diffusion, the permeability A-B and B-A would have to be similar, that is, if the transports coincide it is because there is only transport by passive diffusion but being different implies the existence of transporters. On the other hand, if the B-A permeability of the two cell types is compared, it is observed that in the MDCK-MDR1 type the permeability is higher (significant differences at $p<0.05$ ). This is due to the fact that, the JM-20 is a substrate of the P-glycoprotein transporter (MDR1), which is expressed in this cell line and, therefore, it promotes the passage of the drug to the apical compartment. Comparing the values obtained in the A-B direction, the previous conclusion is corroborated, with a slightly greater permeability in MDCK cells, since resistance due to the secretion transporter is not present, but no statistical differences were detected.

However, when comparing the permeability values (A-B) obtained in both MDCK cell lines with the permeability value of metoprolol (See Figure 2), it is possible to verify that although the compound is a substrate of a secretion transporter, the absorption transporter must have greater affinity for the drug, therefore according to the effective permeability obtained, JM-20 can be classified as a highly permeable drug.

In the case of Caco- 2 cells, results similar to those of MDCK cells were obtained. In vitro bidirectional transport of JM-20 in Caco-2 cells showed that the absorptive transport of this compound was greater than its secretory transport, with an efflux ratio of 0.13 . The calculated absorptive permeability of JM-20 in the Caco-2 cell monolayer was $18.50 \times 10^{-5} \mathrm{~cm} / \mathrm{s}$, suggesting efficient permeability of this novel compound [63].

The high permeability value obtained in the Caco- 2 model is consistent with the permeability value obtained in the rats. As can be seen in Figure 3, which represents the fraction absorbed versus permeability values relationship in both absorption models, the permeability values of JM-20 fit perfectly with the correlation validated previously. Lozoyaagullo et al. [64,65] have previously demonstrated the excellent correlation between the permeabilities of the Caco- 2 model and the rat intestinal permeabilities obtained with the closed-loop perfusion technique in rat and the ability of both models to predict oral fraction absorbed in humans. The new compound assayed JM-20 confirms that permeability values greater than $1.0 \times 10^{-5} \mathrm{~cm} / \mathrm{s}$ in Caco-2 and $6.0 \times 10^{-5} \mathrm{~cm} / \mathrm{s}$ in rat guarantee a nearly complete fraction absorbed.

Considering that JM-20 is a neuroprotective drug and that the purposes of the treatments are chronic diseases, it is interesting to know in depth the permeability of this compound in the intestinal tract since for a chronic disease the oral route of administration may facilitate patient compliance. For this purpose, the in situ intestinal perfusion method was applied in rats. This technique has demonstrated its high correlation $\left(r^{2}>0.80\right)$ with permeability values in humans for substances with a combined absorption process: passive diffusion and carrier-mediated mechanism [66,67], as well as being considered a good model for the prediction of intestinal permeability in humans [10].

The permeability of JM-20 in the duodenum was higher than that of the other two intestinal segments, suggesting that this compound could be well absorbed throughout the gut with the main site of absorption in the duodenum. For the jejunum and ileum segments, permeability values were similar but lower compared with the duodenum, which could be related to higher levels of Pgp expression in these segments that reduce the permeation of JM-20 across the intestinal membrane.

The permeability values obtained in the different intestinal sections (See Table 4) corroborate the results obtained in the cell lines. For all the "High permeability" compounds in human (Fabs $>85 \%$ ), with differential permeability along the small intestine, showed at least in one segment a higher permeability value than metoprolol in that same segment. This supports that if a compound has a high absorbed dose fraction, it will have a highpermeability, not necessarily in the jejunum, but somewhere along the relevant intestinal 
absortive regions $[64,68]$. Correlations between permeability values in the rat small intestine (whole or segments) obtained by Doluisio's method and their correlation with the orally absorbed fraction in humans were previously published [64,65]. In fact, Fabs can be calculated considering the permeability values in all segments (whole small intestine) and the estimated oral absorbed fraction was $85.12 \%$. According to this property, the drug may be a good candidate to be formulated for oral administration.

Once the experimental results obtained have been analyzed, we can assure that JM-20 has a low solubility and high intestinal permeability, therefore it belongs to Class 2 of the BCS. The absorption of the drug in this case is limited by its solubility, being this the factor to be improved during the pre-formulation of this API for oral administration.

Many drugs belong to BCS Class 2 are weak bases, with higher solubility at low $\mathrm{pH}$ values in the stomach, but lower solubility at near neutral $\mathrm{pH}$ in distal segments of the small intestine. These drugs can dissolve at gastric $\mathrm{pH}$ facilitating ionization, but their absorption is quite low in the stomach. However, in the case of small intestine, where most drugs are absorbed, higher $\mathrm{pH}$ values and lower solubility may affect oral absorption [69].

\section{Conclusions}

In this study, a pH-dependent solubility assay of JM-20 was performed. The $\mathrm{pKa}$ and solubility values confirm that this weakly basic compound has a low $\mathrm{pH}$-dependent solubility; thus, in the physiological $\mathrm{pH}$ range, the dose is not expected to dissolve completely, and dissolution is likely to be the rate-limiting process of its absorption. In vitro permeability assays suggest that an absorption transport mechanism exists in the permeation of JM-20 across the membrane and that this compound is also a substrate of P-glycoprotein. The application of the Doluisio closed-loop in situ perfusion technique in rats allowed to evaluate the effective permeability of the compound, demonstrating the high permeability of this drug compared to metoprolol. Finally, this new chemical entity was classified as BCS class 2 due to its low solubility and high intestinal permeability. These results provide the fundamental basis for the development of an oral formulation that will be evaluated in preclinical trials and will allow further development of this molecule as a neuroprotectant against cerebral ischemia.

Author Contributions: Methodology, validation, and investigation, C.M., P.P. and A.R.-P.; formal analysis, writing-original draft preparation, I.G.-A. and A.A.; visualization, supervision, funding acquisition, M.B.; project administration, conceptualization, writing-review and editing and supervision, M.-Á.C.-P. and M.G.-A. All authors have read and agreed to the published version of the manuscript.

Funding: This research was partially funded by Agencia Estatal Investigación and European Union through FEDER (Fondo Europeo de Desarrollo Regional) by the project "Modelos in vitro de evaluación biofarmacéutica", grant number SAF2016-78756 (AEI/FEDER, EU).

Institutional Review Board Statement: The study was conducted according to the guidelines of the Declaration of Helsinki, and approved by the Ethics Committee of Miguel Hernandez University (protocol code 2014.313.E.OEP, 25 November 2014).

Informed Consent Statement: Not applicable.

Acknowledgments: We thank to the Center for Pharmaceutical Research and Development (CIDEM, Havana, Cuba) for the supply of JM-20.

Conflicts of Interest: The authors declare no conflict of interest.

\section{References}

1. Kesisoglou, F.; Wu, Y. Understanding the effect of API properties on bioavailability through absorption modeling. AAPS J. 2008, 10, 516-525. [CrossRef] [PubMed]

2. Amidon, G.L.; Lennernäs, H.; Shah, V.P.; Crison, J.R. A theoretical basis for a biopharmaceutic drug classification: The correlation of in vitro drug product dissolution and in vivo bioavailability. Pharm. Res. 1995, 12, 413-420. [CrossRef] [PubMed] 
3. Ku, M.S. Use of the Biopharmaceutical Classification System in early drug development. AAPS J. 2008, 10, 208-212. [CrossRef] [PubMed]

4. CDER/FDA. FDA Guidance for Industry, Waiver of In Vivo Bioavailability and Bioequivalence Studies for Immediate Release Solid Oral Dosage Forms Based on a Biopharmaceutics Classification System. Center for Drug Evaluation and Research. Available online: https: / / www.fda.gov/media/70963/download (accessed on 11 November 2020).

5. EMA. EMA/CHMP: Guidelines on the Investigation of Bioequivalence; EMA: London, UK, 2010.

6. Lennernäs, H. Human intestinal permeability. J. Pharm. Sci. 1998, 87, 403-410. [CrossRef]

7. Kim, J.S.; Mitchell, S.; Kijek, P.; Tsume, Y.; Hilfinger, J.; Amidon, G.L. The suitability of an in situ perfusion model for permeability determinations: Utility for BCS class I biowaiver requests. Mol. Pharm. 2006, 3, 686-694. [CrossRef]

8. Artursson, P. Epithelial transport of drugs in cell culture. I: A model for studying the passive diffusion of drugs over intestinal absorptive (Caco-2) cells. J. Pharm. Sci. 1990, 79, 476-482. [CrossRef]

9. Irvine, J.D.; Takahashi, L.; Lockhart, K.; Cheong, J.; Tolan, J.W.; Selick, H.E.; Grove, J.R.; Rove, J.R.U.G. MDCK (Madin-Darby canine kidney) cells: A tool for membrane permeability screening. J. Pharm. Sci. 1999, 88, 28-33. [CrossRef]

10. Cabrera-Pérez, M.Á.; Pham-The, H.; Cervera, M.F.; Hernández-Armengol, R.; Miranda-Pérez de Alejo, C.; Brito-Ferrer, Y. Integrating theoretical and experimental permeability estimations for provisional biopharmaceutical classification: Application to the WHO essential medicines. Biopharm. Drug Dispos. 2018, 39, 354-368. [CrossRef]

11. Nuñez-Figueredo, Y.; Ramírez-Sánchez, J.; Delgado-Hernández, R.; Porto-Verdecia, M.; Ochoa-Rodríguez, E.; Verdecia-Reyes, Y.; Marin-Prida, J.; González-Durruthy, M.; Uyemura, S.A.; Rodrigues, F.P.; et al. JM-20, a novel benzodiazepine-dihydropyridine hybrid molecule, protects mitochondria and prevents ischemic insult-mediated neural cell death in vitro. Eur. J. Pharmacol. 2014, 726, 57-65. [CrossRef]

12. Nuñez-Figueredo, Y.; Ramírez-Sánchez, J.; Hansel, G.; Simões Pires, E.N.; Merino, N.; Valdes, O.; Delgado-Hernández, R.; Parra, A.L.; Ochoa-Rodríguez, E.; Verdecia-Reyes, Y.; et al. A novel multi-target ligand (JM-20) protects mitochondrial integrity, inhibits brain excitatory amino acid release and reduces cerebral ischemia injury in vitro and in vivo. Neuropharmacology 2014, 85, 517-527. [CrossRef]

13. Ramírez-Sánchez, J.; Simões Pires, E.N.; Nuñez-Figueredo, Y.; Pardo-Andreu, G.L.; Fonseca-Fonseca, L.A.; Ruiz-Reyes, A.; OchoaRodríguez, E.; Verdecia-Reyes, Y.; Delgado-Hernández, R.; Souza, D.O.; et al. Neuroprotection by JM-20 against oxygen-glucose deprivation in rat hippocampal slices: Involvement of the Akt/GSK-3 $\beta$ pathway. Neurochem. Int. 2015, 90, 215-223. [CrossRef]

14. Nuñez-Figueredo, Y.; Pardo-Andreu, G.L.; Ramírez-Sánchez, J.; Delgado-Hernández, R.; Ochoa-Rodríguez, E.; Verdecia-Reyes, Y.; Naal, Z.; Muller, A.P.; Portela, L.V.; Souza, D.O. Antioxidant effects of JM-20 on rat brain mitochondria and synaptosomes: Mitoprotection against Ca2+-induced mitochondrial impairment. Brain Res. Bull. 2014, 109, 68-76. [CrossRef]

15. Nuñez-Figueredo, Y.; Pardo Andreu, G.L.; Oliveira Loureiro, S.; Ganzella, M.; Ramírez-Sánchez, J.; Ochoa-Rodríguez, E.; Verdecia-Reyes, Y.; Delgado-Hernández, R.; Souza, D.O. The effects of JM-20 on the glutamatergic system in synaptic vesicles, synaptosomes and neural cells cultured from rat brain. Neurochem. Int. 2015, 81, 41-47. [CrossRef]

16. Nuñez-Figueredo, Y.; Ramírez-Sánchez, J.; Pardo Andreu, G.L.; Ochoa-Rodríguez, E.; Verdecia-Reyes, Y.; Souza, D.O. Multitargeting effects of a new synthetic molecule (JM-20) in experimental models of cerebral ischemia. Pharmacol. Reports 2018, 70, 699-704. [CrossRef]

17. Fonseca-Fonseca, L.A.; da Silva, V.D.A.; Wong-Guerra, M.; Ramírez-Sánchez, J.; Yaquis, A.S.P.; Ochoa-Rodríguez, E.; VerdeciaReyes, Y.; de Araújo, F.M.; Santana, R.C.; Outeiro, T.F.; et al. JM-20 protects against 6-hydroxydopamine-induced neurotoxicity in models of Parkinson's disease: Mitochondrial protection and antioxidant properties. Neurotoxicology 2021, 82, 89-98. [CrossRef]

18. Wong-Guerra, M.; Montano-Peguero, Y.; Ramírez-Sánchez, J.; Jiménez-Martin, J.; Fonseca-Fonseca, L.A.; Hernández-Enseñat, D.; Nonose, Y.; Valdés, O.; Mondelo-Rodriguez, A.; Ortiz-Miranda, Y.; et al. JM-20 treatment prevents neuronal damage and memory impairment induced by aluminum chloride in rats. Neurotoxicology 2021, 87. [CrossRef]

19. Wong-Guerra, M.; Jiménez-Martin, J.; Fonseca-Fonseca, L.A.; Ramírez-Sánchez, J.; Montano-Peguero, Y.; Rocha, J.B.; D’ Avila, F.; de Assis, A.M.; Souza, D.O.; Pardo-Andreu, G.L.; et al. JM-20 protects memory acquisition and consolidation on scopolamine model of cognitive impairment. Neurol. Res. 2019, 41. [CrossRef]

20. ChemAxon MarvinSketch 5.3.7, ChemAxon Ltd. Budapest, Hungary. Available online: http://www.chemaxon.com (accessed on 5 January 2021).

21. Falcón-Cano, G.; Molina, C.; Cabrera-Pérez, M.Á. ADME prediction with KNIME: In silico aqueous solubility consensus model based on supervised recursive random forest approaches. Admet Dmpk 2020, 8, 1-23.

22. Falcón-Cano, G.; Molina, C.; Cabrera-Pérez, M.Á. ADME Prediction with KNIME: Development and Validation of a Publicly Available Workflow for the Prediction of Human Oral Bioavailability. J. Chem. Inf. Model. 2020, 60, 2660-2667. [CrossRef]

23. Figueredo, Y.N.; Rodríguez, E.O.; Reyes, Y.V.; Domínguez, C.C.; Parra, A.L.; Sánchez, J.R.; Hernández, R.D.; Verdecia, M.P.; Pardo Andreu, G.L. Characterization of the anxiolytic and sedative profile of JM-20: A novel benzodiazepine-dihydropyridine hybrid molecule. Neurol. Res. 2013, 35, 804-812. [CrossRef]

24. Martínez, C.H.R.; Dardonville, C. Rapid Determination of Ionization Constants ( $\mathrm{p}$ K a ) by UV Spectroscopy Using 96-Well Microtiter Plates. ACS Med. Chem. Lett. 2013, 4, 142-145. [CrossRef]

25. Formulary, U.S.P.N. United States Pharmacopeia and National Formulary (USP 38-NF 33). In Proceedings of the United States Pharmacopeia Convention; The United States Pharmacopeial Convention: North Bethesda, MD, USA, 2015. 
26. Salgado, L.E.V.; Vargas-Hernández, C. Spectrophotometric Determination of the pKa, Isosbestic Point and Equation of Absorbance vs. pH for a Universal pH Indicator. Am. J. Anal. Chem. 2014, 05, 1290-1301. [CrossRef]

27. WHO. Multisource (Generic) Pharmaceutical Products: Guidelines on Registration Requirements to Establish Interchangeability Annex 6, WHO Technical Report Series, No. 1003; WHO: Geneva, Switzerland, 2017; pp. 181-236.

28. Baka, E.; Comer, J.E.A.; Takács-Novák, K. Study of equilibrium solubility measurement by saturation shake-flask method using hydrochlorothiazide as model compound. J. Pharm. Biomed. Anal. 2008, 46, 335-341. [CrossRef]

29. Avdeef, A.; Fuguet, E.; Llinàs, A.; Ràfols, C.; Bosch, E.; Völgyi, G.; Verbić, T.; Boldyreva, E.; Novák, K.T. Equilibrium solubility measurement of ionizable drugs-Consensus recommendations for improving data quality. Admet Dmpk 2016, 4, 117-178. [CrossRef]

30. pDISOL-X Software I in-ADME Research. Available online: https://www.in-adme.com/pdisol_x.html (accessed on 5 January 2021).

31. Völgyi, G.; Marosi, A.; Novák, K.T.; Avdeef, A. Salt Solubility Products of Diprenorphine Hydrochloride, Codeine and Lidocaine Hydrochlorides and Phosphates-Novel Method of Data Analysis Not Dependent on Explicit Solubility Equations. Admet Dmpk 2013, 1, 48-62. [CrossRef]

32. Mangas-Sanjuan, V.; Gonzalez, I.; Gonzalez, M.; Casabo, V.G.; Bermejo, M. Modified Nonsink Equation for Permeability Estimation in Cell Monolayers: Comparison with Standard Methods. Mol. Pharm. 2014, 11, 1403-1414. [CrossRef]

33. Doluisio, J.T.; Billups, N.F.; Dittert, L.W.; Sugita, E.T.; Swintosky, J. V Drug Absorption I: An in situ Rat Gut Technique Yielding Realistic Absorption Rates. J. Pharm. Sci. 1969, 58, 1196-1200. [CrossRef]

34. Saitoh, H.; Hatakeyama, M.; Eguchi, O.; Oda, M.; Takada, M. Involvement of intestinal P-glycoprotein in the restricted absorption of methylprednisolone from rat small intestine. J. Pharm. Sci. 1998, 87, 73-75. [CrossRef]

35. Casabo, V.G.; Nunez-Benito, E.; Martinez-Coscolla, A.; Miralles-Loyola, E.; Martin-Villodre, A.; Pla-Delfina, J.M. Studies on the reliability of a bihyperbolic functional absorption model. II. Phenylalkylamines. J. Pharm. Biopharm. 1987, 15, 633-643. [CrossRef]

36. Ferrando, R.; Garrigues, T.M.; Bermejo, M.V.; Martin-Algarra, R.; Merino, V.; Polache, A. Effects of ethanol on intestinal absorption of drugs: In situ studies with ciprofloxacin analogs in acute and chronic alcohol-fed rats. Alcohol. Clin. Exp. Res. 1999, 23, 1403-1408. [CrossRef]

37. Bermejo, M.; Merino, V.; Garrigues, T.M.; Pla Delfina, J.M.; Mulet, A.; Vizet, P.; Trouiller, G.; Mercier, C. Validation of a biophysical drug absorption model by the PATQSAR system. J. Pharm. Sci. 1999, 88, 398-405. [CrossRef] [PubMed]

38. Ruiz-Garcia, A.; Bermejo, M.; Merino, V.; Sanchez-Castano, G.; Freixas, J.; Garrigues, T.M. Pharmacokinetics, bioavailability and absorption of flumequine in the rat. Eur. J. Pharm. Biopharm. 1999, 48, 253-258. [CrossRef]

39. Gomes de Souza, D.; Batista Calixto, J.; Siqueira Junior, J.; Heller, M.; Cristina Schwanke, R.; Avila Silveira, F. Desenvolvimento e Validação Simplificada de Método Analítico para a Substância Teste 079. Available online: https://repositorio.unesp.br/ bitstream/handle/11449/155536/000885540.pdf?sequence=1\&isAllowed=y (accessed on 5 January 2021).

40. Tuğcu-Demiröz, F.; Gonzalez-Alvarez, I.; Gonzalez-Alvarez, M.; Bermejo, M. Validation of phenol red versus gravimetric method for water reabsorption correction and study of gender differences in Doluisio's absorption technique. Eur. J. Pharm. Sci. 2014, 62, 105-110. [CrossRef] [PubMed]

41. Martin-Villodre, A.; Pla-Delfina, J.M.; Moreno, J.; Pérez-Buendía, D.; Miralles, J.; Collado, E.F.; Sánchez-Moyano, E.; del Pozo, A Studies on the Reliability of a Bihyperbolic Functional Absorption Model. I.Ring-Substituted Anilines. J. Pharmacokinet. Biopharm. 1986, 14, 615-633. [CrossRef]

42. Lipinski, C.A.; Lombardo, F.; Dominy, B.W.; Feeney, P.J. Experimental and computational approaches to estimate solubility and permeability in drug discovery and development settings. Adv. Drug. Deliv. Rev. 1997, 23, 3-25. [CrossRef]

43. Veber, D.F.; Johnson, S.R.; Cheng, H.Y.; Smith, B.R.; Ward, K.W.; Kopple, K.D. Molecular properties that influence the oral bioavailability of drug candidates. J. Med. Chem. 2002, 45, 2615-2623. [CrossRef]

44. Martínez Alvarez, L.; Alejo Cisneros, P.L.; Forte Mesa, R.F.; Quiñones Hinojosa, L.; Mondelo Rodríguez, A.; García Borges, L.; Guerra Menéndez, H.; Tuero Iglesias, A.; Ochoa Rodríguez, E.; Cabrera-Pérez, M.A.; et al. Solubilidad de equilibrio usando el método de agitación de matraces saturados de JM-20: Molécula sintética con acción neuroprotectora. J. Pharm. Pharmacogn. Res. 2020, 8, 117-126.

45. Kasim, N.A.; Whitehouse, M.; Ramachandran, C.; Bermejo Sanz, M.; Lennernäs, H.; Hussain, A.S.; Junginger, H.E.; Stavchansky S.A.; Midha, K.K.; Shah, V.P.; et al. Molecular Properties of WHO Essential Drugs and Provisional Biopharmaceutical Classification. Mol. Pharm. 2004, 1, 85-96. [CrossRef]

46. Butler, J.M.; Dressman, J.B. The developability classification system: Application of biopharmaceutics concepts to formulation development. J. Pharm. Sci. 2010, 99, 4940-4954. [CrossRef]

47. $\mathrm{Wu}, \mathrm{C} . Y . ;$ Benet, L.Z. Predicting drug disposition via application of BCS: Transport/absorption/ elimination interplay and development of a biopharmaceutics drug disposition classification system. Pharm. Res. 2005, 22, 11-23. [CrossRef]

48. Pham-The, H.; Garrigues, T.; Bermejo, M.; González-Álvarez, I.; Monteagudo, M.C.; Cabrera-Pérez, M.Á. Provisional Classification and in Silico Study of Biopharmaceutical System Based on Caco-2 Cell Permeability and Dose Number. Mol. Pharm. 2013, 10, 2445-2461. [CrossRef]

49. Dahan, A.; Wolk, O.; Kim, Y.H.; Ramachandran, C.; Crippen, G.M.; Takagi, T.; Bermejo, M.; Amidon, G.L. Purely in Silico BCS Classification: Science Based Quality Standards for the World's Drugs. Mol. Pharm. 2013, 10, 4378-4390. [CrossRef] 
50. Lozoya-Agullo, I.; González-Álvarez, I.; González-Álvarez, M.; Merino-Sanjuán, M.; Bermejo, M. In Situ Perfusion Model in Rat Colon for Drug Absorption Studies: Comparison with Small Intestine and Caco-2 Cell Model. J. Pharm. Sci. 2015, 104, 3136-3145. [CrossRef]

51. Avdeef, A. Physicochemical Profiling (Solubility, Permeability and Charge State). Front. Med. Chem. 2004, 1, 409-475. [CrossRef]

52. Egan, W.J.; Merz, K.M., Jr.; Baldwin, J.J. Prediction of drug absorption using multivariate statistics. J. Med. Chem. 2000, 43, 3867-3877. [CrossRef]

53. Waring, M.J. Defining optimum lipophilicity and molecular weight ranges for drug candidates-Molecular weight dependent lower $\log \mathrm{D}$ limits based on permeability. Bioorg. Med. Chem. Lett. 2009, 19, 2844-2851. [CrossRef]

54. Pham-The, H.; González-Álvarez, I.; Bermejo, M.; Garrigues, T.; Le-Thi-Thu, H.; Cabrera-Pérez, M.Á. The use of rule-based and QSPR approaches in ADME profiling: A case study on caco-2 permeability. Mol. Inform. 2013, 32, 459-479. [CrossRef]

55. Sun, N.; Avdeef, A. Biorelevant $\mathrm{p} \mathrm{K} \mathrm{a}\left(37^{\circ} \mathrm{C}\right)$ predicted from the $2 \mathrm{D}$ structure of the molecule and its pKa at $25^{\circ} \mathrm{C}$. $J . P h a r m$. Biomed. Anal. 2011, 56, 173-182. [CrossRef]

56. Williams, R.O., III; Watts, A.B.; Miller, D.A. Formulating Poorly Water Soluble Drugs; Springer: Berlin/Heidelberg, Germany, 2012; Volume 22, ISBN 9781461411437.

57. Rodriguez-Aller, M.; Guillarme, D.; Veuthey, J.L.; Gurny, R. Strategies for formulating and delivering poorly water-soluble drugs J. Drug Deliv. Sci. Technol. 2015, 30, 342-351. [CrossRef]

58. Miyake, M.; Koga, T.; Kondo, S.; Yoda, N.; Emoto, C.; Mukai, T.; Toguchi, H. Prediction of drug intestinal absorption in human using the Ussing chamber system: A comparison of intestinal tissues from animals and humans. Eur. J. Pharm. Sci. 2017, 96. [CrossRef]

59. Hubatsch, I.; Ragnarsson, E.G.E.; Artursson, P. Determination of drug permeability and prediction of drug absorption in Caco-2 monolayers. Nat. Protoc. 2007, 2, 2111-2119. [CrossRef]

60. Kawabata, Y.; Wada, K.; Nakatani, M.; Yamada, S.; Onoue, S. Formulation design for poorly water-soluble drugs based on biopharmaceutics classification system: Basic approaches and practical applications. Int. J. Pharm. 2011, 420, 1-10. [CrossRef]

61. Vemula, V.R.; Lagishetty, V.; Lingala, S. Solubility enhancement techniques. Int. J. Pharm. Sci. Rev. Res. 2010, 5, 41-51.

62. Singh, A.; Worku, Z.A.; Van Den Mooter, G. Oral formulation strategies to improve solubility of poorly water-soluble drugs. Expert Opin. Drug Deliv. 2011, 8, 1361-1378. [CrossRef]

63. Volpe, D.A.; Faustino, P.J.; Ciavarella, A.B.; Asafu-Adjaye, E.B.; Ellison, C.D.; Yu, L.X.; Hussain, A.S. Classification of drug permeability with a Caco-2 cell monolayer assay. Clin. Res. Regul. Aff. 2007, 24, 39-47. [CrossRef]

64. Lozoya-Agullo, I.; Zur, M.; Beig, A.; Fine, N.; Cohen, Y.; González-Álvarez, M.; Merino-Sanjuán, M.; González-Álvarez, I.; Bermejo, M.; Dahan, A. Segmental-dependent permeability throughout the small intestine following oral drug administration: Single-pass vs. Doluisio approach to in-situ rat perfusion. Int. J. Pharm. 2016, 515, 201-208. [CrossRef]

65. Lozoya-Agullo, I.; Zur, M.; Wolk, O.; Beig, A.; González-Álvarez, I.; González-Álvarez, M.; Merino-Sanjuán, M.; Bermejo, M.; Dahan, A. In-situ intestinal rat perfusions for human Fabs prediction and BCS permeability class determination: Investigation of the single-pass vs. the Doluisio experimental approaches. Int. J. Pharm. 2015, 480, 1-7. [CrossRef]

66. Cao, X.; Gibbs, S.T.; Fang, L.; Miller, H.A.; Landowski, C.P.; Shin, H.-C.C.; Lennernäs, H.; Zhong, Y.; Amidon, G.L.; Yu, L.X.; et al. Why is it challenging to predict intestinal drug absorption and oral bioavailability in human using rat model. Pharm. Res. 2006, 23, 1675-1686. [CrossRef] [PubMed]

67. Zakeri-Milani, P.; Valizadeh, H.; Tajerzadeh, H.; Azarmi, Y.; Islambolchilar, Z.; Barzegar, S.; Barzegar-Jalali, M. Predicting human intestinal permeability using single-pass intestinal perfusion to rat. J. Pharm. Pharm. Sci. 2007, 10, 368-379. [PubMed]

68. Dahan, A.; Miller, J.M.; Hilfinger, J.M.; Yamashita, S.; Yu, L.X.; Lennernäs, H.; Amidon, G.L. High-permeability criterion for BCS classification: Segmental/pH dependent permeability considerations. Mol. Pharm. 2010, 7, 1827-1834. [CrossRef] [PubMed]

69. Kou, D.; Zhang, C.; Yiu, H.; Ng, T.; Lubach, J.W.; Janson, M.; Mao, C.; Durk, M.; Chinn, L.; Winter, H.; et al. In Vitro, In Silico, and In Vivo Assessments of Intestinal Precipitation and Its Impact on Bioavailability of a BCS Class 2 Basic Compound. Mol. Pharm. 2018, 15, 1607-1617. [CrossRef] 